\title{
Bone meal as a source of phosphorus for forage sugarcane ${ }^{1}$
}

\author{
Wesley Mendes da Silva ${ }^{2}$, Marco Antonio Camillo de Carvalho², \\ Oscar Mitsuo Yamashita ${ }^{2}$, Tauan Rimoldi Tavanti ${ }^{3}$, Renan Francisco Rimoldi Tavanti ${ }^{3}$
}

\begin{abstract}
Phosphate fertilizers of organic origin may represent a viable alternative for the replacement of mineral fertilizers in the nutrition of crops such as forage sugarcane. This study aimed to investigate the effects of phosphate fertilization with bone meal and single superphosphate on the concentration of phosphorus (P) in the plant tissue, total soluble solids and yield aspects of forage sugarcane. A complete randomized block design was used, in a $2 \times 5$ factorial scheme, with four replicates. The treatments consisted of combining two phosphorus sources (single superphosphate and bone meal) and five $\mathrm{P}_{2} \mathrm{O}_{5}$ doses $\left(0 \mathrm{~kg} \mathrm{ha}^{-1}, 50 \mathrm{~kg} \mathrm{ha}^{-1}, 100 \mathrm{~kg} \mathrm{ha}^{-1}, 150 \mathrm{~kg} \mathrm{ha}^{-1}\right.$ and $\left.200 \mathrm{~kg} \mathrm{ha}^{-1}\right)$. Sugarcane plants fertilized with the addition of bone meal showed an increase in height and number of nodes (13\% and $15 \%$, respectively), when compared to the mineral fertilization with single superphosphate. The sugarcane attributes, in response to the $\mathrm{P}_{2} \mathrm{O}_{5}$ doses, were described by quadratic functions. The dose of $95.80 \mathrm{~kg} \mathrm{ha}^{-1}$ of $\mathrm{P}_{2} \mathrm{O}_{5}$ in the bone meal led to the highest concentration of $\mathrm{P}$ in the plant tissue (3.60 $\left.\mathrm{g} \mathrm{kg}^{-1}\right)$. The comparison between the sources of $\mathrm{P}$ at the doses of $100 \mathrm{~kg} \mathrm{ha}^{-1}$ and $150 \mathrm{~kg} \mathrm{ha}^{-1}$ of $\mathrm{P}_{2} \mathrm{O}_{5}$ showed that the total soluble solids content was $8.62 \%$ and $13.84 \%$ higher, respectively, in plants fertilized with bone meal.
\end{abstract}

KEYWORDS: Saccharum officinarum, organic fertilizer, phosphate, mineral plant nutrition.

\section{INTRODUCTION}

Phosphorus (P) is considered a "key nutrient" in the achievement of high yields in sugarcane crops (Sundara et al. 2002). It has a direct influence on the quality of the produced sugar and alcohol because it participates in metabolic reactions of storage and energy supply via molecules of adenosine triphosphate (ATP) (Blackburn 1984, Locher 2016). Phosphorus

\section{RESUMO}

Farinha de ossos como fonte de fósforo para a cultura da cana-de-açúcar forrageira

Adubos fosfatados de origem orgânica podem apresentar-se como alternativas viáveis para a substituição de adubos minerais na nutrição de culturas como a cana-de-açúcar forrageira. Objetivou-se investigar os efeitos da adubação fosfatada com farinha de ossos e superfosfato simples sobre a concentração de fósforo $(\mathrm{P})$ no tecido vegetal, sólidos solúveis totais e aspectos produtivos da cana-deaçúcar forrageira. Utilizou-se o delineamento experimental de blocos casualizados, em esquema fatorial $2 \times 5$, com quatro repetições, sendo os tratamentos compostos pela combinação de duas fontes de fósforo (superfosfato simples e farinha de ossos) e cinco doses de $\mathrm{P}_{2} \mathrm{O}_{5}\left(0 \mathrm{~kg} \mathrm{ha}^{-1}, 50 \mathrm{~kg} \mathrm{ha}^{-1}, 100 \mathrm{~kg} \mathrm{ha}^{-1}, 150 \mathrm{~kg} \mathrm{ha}^{-1}\right.$ e $\left.200 \mathrm{~kg} \mathrm{ha}^{-1}\right)$. A adubação com farinha de ossos incrementou a altura e o número de nós da cana-de-açúcar em $13 \%$ e $15 \%$, respectivamente, quando comparada à adubação mineral com superfosfato simples. Os atributos da cana-de-açúcar, em resposta às doses de $\mathrm{P}_{2} \mathrm{O}_{5}$, foram descritos por funções quadráticas. A dose de $95,80 \mathrm{~kg} \mathrm{ha}^{-1}$ de $\mathrm{P}_{2} \mathrm{O}_{5}$ na fonte farinha de ossos proporcionou a maior concentração de $\mathrm{P}$ no tecido vegetal $\left(3,60 \mathrm{~g} \mathrm{~kg}^{-1}\right)$. Comparando-se as fontes de $\mathrm{P}$ propostas nas doses de $100 \mathrm{~kg} \mathrm{ha}^{-1}$ e $150 \mathrm{~kg} \mathrm{ha}^{-1} \mathrm{de}_{2} \mathrm{O}_{5}$, observouse que o teor de sólidos solúveis totais foi $8,62 \%$ e $13,84 \%$ maior, respectivamente, em plantas adubadas com farinha de osso.

PALAVRAS-CHAVE: Saccharum officinarum, adubo orgânico, fosfato, nutrição mineral de plantas.

also plays an important role in the cell structure, being a component of phospholipid membranes and RNA and DNA nucleotide ribbons (Yeagle 2016). An adequate supply of $\mathrm{P}$ is, therefore, crucial from initial stages of plant growth. Limitations on the availability of $\mathrm{P}$ at the start of the vegetative cycle may result in developmental constraints, from which the plant will not recover later, even after increased supplies of $\mathrm{P}$ at appropriate levels (Grant et al. 2001).

1. Received: Oct. 30, 2018. Accepted: May 21, 2019. Published: Jul. 18, 2019. DOI: 10.1590/1983-40632019v4955629.

2. Universidade do Estado de Mato Grosso, Departamento de Agronomia, Alta Floresta, MT, Brasil.

E-mail/ORCID: wesleymesi@outlook.com/0000-0001-9573-918X, marcocarvalho@unemat.br/0000-0003-4966-1013, yama@unemat.br/0000-0001-6715-626X.

3. Universidade Estadual Paulista "Júlio de Mesquita Filho", Faculdade de Engenharia, Ilha Solteira, SP, Brasil.

E-mail/ORCID: tauanrt@outlook.com/0000-0001-6915-1702, renan.tavanti@hotmail.com/0000-0002-4496-9660. 
The vast majority of tropical soils naturally has concentrations of $\mathrm{P}$ available below that required for most crops (Withers et al. 2018). This is mainly due to the presence of iron and aluminum oxides in the mineral fraction, which are mainly responsible for the retention of phosphate ions (Casagrande et al. 2003). In addition, the $\mathrm{pH}$ variation of these soils may directly influence the proportion of $\mathrm{H}_{2} \mathrm{PO}_{4}{ }^{-}$and $\mathrm{HPO}_{4}{ }^{2-}$ anions in the solution, balance of negative and positive electric charges and formation of amorphous aluminum polymers, such as $\mathrm{Al}(\mathrm{OH})_{3}$, which increase the retention capacity of phosphate ions (Haynes 1982).

High solubility mineral fertilizers [e.g.: single superphosphate, triple superphosphate, monoammonium phosphate (MAP) and diammonium phosphate (DAP)] are the main soluble sources of $\mathrm{P}$ for crops, corresponding to more than $90 \%$ of the $\mathrm{P}_{2} \mathrm{O}_{5}$ equivalent used in the Brazilian agriculture, and show a high agronomic efficiency, in terms of solubility, in a short period of time (Caione et al. 2011). On the other hand, their cost is high, in comparison to other phosphatic fertilizers, representing a considerable share in the production cost of crops.

In this sense, alternative sources of $\mathrm{P}$, such as organic or organomineral fertilizers, have drawn the attention of farmers and researchers, basically due to the low cost and slow-release/mineralization of $\mathrm{P}$ fertilizers (Boen \& Haraldsen 2013). Bone meal, for example, is a by-product from animal slaughtering in slaughterhouses (Cavallaro Júnior 2006), being a residue that is difficult to dispose of. It is considered a first order fertilizer, presenting a reaction in the soil in a few days after its application (Caione et al. 2011). This behavior of slow mineralization of $P$ may be used as a strategy to increase the agronomic efficiency of phosphate fertilization in soils of high degree of weathering, such as the soils in the northern regions of the Mato Grosso state, Brazil.

Studies have reported that the period of greatest demand for P in crops such as sunflower (Zobiole et al. 2010), corn (Von Pinho et al. 2010) and soybean (Oliveira Júnior et al. 2014) is between 70 and 100 days after sowing. For sugarcane, there is currently no information on the period of greatest demand or absorption of P. However, it is known that it must be applied at the time of planting, and this ensures, in most cases, the supply for the first regrowth (Oliveira et al. 2007). It is also recommended to use $P$ in the fertilization of later shoots, in order to guarantee the highest possible yield. Based on this information, it is assumed that the supply of $\mathrm{P}$, using organic or organomineral fertilizers, can occur more consistently with the crop cycle, and it is the most plausible option with its respective $\mathrm{P}$ uptake.

This study examines the hypothesis that phosphate fertilizers with bone meal and simple superphosphate as sources should present different responses in the development of forage sugarcane in the northern region of the Mato Grosso state. Thus, it aimed to investigate the effects of phosphate fertilization in furrows with bone meal and simple superphosphate on the $\mathrm{P}$ concentration in the tissue, total soluble solids and yield aspects of the plant.

\section{MATERIAL AND METHODS}

The study was carried out in a rural property located in Alta Floresta, Mato Grosso state, Brazil (54 57'50.9'S, 947'5.1'W and approximately $270 \mathrm{~m}$ of altitude). The predominant climate in the region, under the Köppen classification, is Am, tropical, with two well-defined seasons: dry in the winter and rainy in the summer. The annual temperature and precipitation are, on average, $26{ }^{\circ} \mathrm{C}$ and 2,400 $\mathrm{mm}$, respectively.

The soil of the experimental site was classified as a Dystrophic Red-Yellow Latosol (Embrapa 2018), with a clayey-sandy loam texture and $332 \mathrm{~g} \mathrm{~kg}^{-1}$ of clay, $122 \mathrm{~g} \mathrm{~kg}^{-1}$ of silt and $546 \mathrm{~g} \mathrm{~kg}^{-1}$ of sand, showing the following chemical characteristics in the 0.00-0.20 m layer: organic matter: $87 \mathrm{~g} \mathrm{~kg}^{-1}$; $\mathrm{pH}$ in $\mathrm{CaCl}_{2}: 4.3 ; \mathrm{P}$ (resin): $3.5 \mathrm{mg} \mathrm{dm}^{-3}$; potassium: $0.05 \mathrm{cmol} \mathrm{dm}^{-3}$; calcium: $0.30 \mathrm{cmol}_{\mathrm{c}} \mathrm{dm}^{-3}$; magnesium: $0.08 \mathrm{cmol}_{\mathrm{c}} \mathrm{dm}^{-3}$; aluminum: $0.95 \mathrm{cmol}_{\mathrm{c}} \mathrm{dm}^{-3}$; potential acidity $(\mathrm{H}+\mathrm{Al}): 4.4 \mathrm{cmol}_{\mathrm{c}} \mathrm{dm}^{-3}$; cation exchange capacity: $4.83 \mathrm{cmol}_{\mathrm{c}} \mathrm{dm}^{-3}$; base saturation: $8.9 \%$.

The preparation of the area began at 60 days before the start of the experiment (August 2014), with the application of dolomitic limestone (PRNT $=85 \%)$ at a dose of $2.33 \mathrm{Mg} \mathrm{ha}^{-1}$ for soil acidity correction (Ribeiro et al. 1999), with the method of increasing the soil base saturation to $60 \%$. Subsequently, limestone was added using a heavy harrow, and the terrain was leveled using a lightweight harrow.

After 60 days (October 2014), furrows of $0.20 \mathrm{~m}$ in depth were opened at $1.20 \mathrm{~m}$ inter row spacing and fertilized with $\mathrm{KCl}$ at a dose of $200 \mathrm{~kg} \mathrm{ha}^{-1}$. Afterwards, forage sugarcane stalk pieces (IAC 86-2480) were planted and positioned side by 
side in an in-line system, at $0.10 \mathrm{~m}$ inter row spacing, containing three to four buds per stalk, and then covered with soil. IAC 86-2480 was chosen because it has the following plant breeding characteristics: high sugar content $\left(15-20 \mathrm{Mg} \mathrm{ha}^{-1}\right.$ of total digestible nutrients); low neutral detergent fiber content; good feed conversion ratio; good agricultural productivity (80-120 Mg ha-1 of fresh mass); stalk longevity; stalk erectness; spontaneous defoliation; uniformity of height and stem diameter; and higher cutting yield (Landell et al. 2002).

A randomized complete block design was used in a $2 \times 5$ factorial scheme, with four replicates. The treatments consisted of two phosphorus sources [simple superphosphate $\left(18 \%\right.$ of $\left.\mathrm{P}_{2} \mathrm{O}_{5}\right)$ and bone meal $\left(33 \%\right.$ of $\mathrm{P}_{2} \mathrm{O}_{5}, 23 \%$ of $\mathrm{P}_{2} \mathrm{O}_{5}$ soluble in citric acid at $2 \%)]$ and five doses of $\mathrm{P}_{2} \mathrm{O}_{5}\left(0 \mathrm{~kg} \mathrm{ha}^{-1}, 50 \mathrm{~kg} \mathrm{ha}^{-1}\right.$, $100 \mathrm{~kg} \mathrm{ha}^{-1}, 150 \mathrm{~kg} \mathrm{ha}^{-1}$ and $200 \mathrm{~kg} \mathrm{ha}^{-1}$ ) applied at the time of planting together with $\mathrm{KCl}\left(160 \mathrm{~kg} \mathrm{ha}^{-1}\right.$ of $\mathrm{K}_{2} \mathrm{O}$ ). The chemical characteristics of the bone meal used in the study were: $14.4 \%$ of P; $36.7 \%$ of $\mathrm{Ca} ; 9.92 \%$ of $\mathrm{SiO}_{2} ; 0.30 \%$ of $\mathrm{S} ; 8,650 \mathrm{mg} \mathrm{kg}^{-1}$ of $\mathrm{Na} ; 239 \mathrm{mg} \mathrm{kg}^{-1}$ of $\mathrm{Zn} ; 12,450 \mathrm{mg} \mathrm{kg}{ }^{-1}$ of $\mathrm{Fe}$; and $0.7 \mathrm{mg} \mathrm{kg}^{-1}$ of Co.

Each experimental plot had 6 rows of $6 \mathrm{~m}$ in length, at $1 \mathrm{~m}$ inter row spacing, thus having a dimension of $36 \mathrm{~m}^{2}$. A useful area was established, comprising the three central rows of the plot, so one meter of border from both ends was not considered.

The weed control was performed by manual plucking at 40 and 90 days after planting the stalk pieces. There was no need for the application of pesticides aimed at the control of insect pests or diseases, as low incidence thereof was observed.

For the monitoring of climatic conditions, the study used data obtained from the weather station of Alta Floresta (Figure 1).

At 360 days after planting, the tillers from the plants in the useful area of the experimental plots were counted. After counting, the tillers were cut in a way to form bundles corresponding to each plot (Caione et al. 2013).

With the aid of a caliper, the stem diameters of ten tillers per plot were measured at the base, middle and apex, thus obtaining the mean diameter. In addition, the tillers were measured for average height according to the distance between the stem base and the visible auricular region (collar) on the leaf. The number of internodes was determined by the average internode count in the ten tillers.
The fresh mass yield was determined by weighing the bundles, expressed in $\mathrm{kg} \mathrm{ha}^{-1}$. To determine the dry mass and plant mass, the material was ground in a hammer mill and samples of $500 \mathrm{~g}$ were removed and oven-dried at $65{ }^{\circ} \mathrm{C}$ to constant weight, expressed in $\mathrm{kg} \mathrm{ha}^{-1}$ and $\mathrm{kg}_{\text {plant }}{ }^{-1}$.

Samples of the dried material were withdrawn and crushed again in a Wiley-type mill until passing through $1 \mathrm{~mm}$ or 20 mesh sieves. With this, $0.25 \mathrm{~g}$ were weighed for determining the concentration of $\mathrm{P}$ in the plant tissue (stem + leaves), following the vanadomolybdic phosphoric acid method (Malavolta et al. 1997).

A portable refractometer, model RT-280, was used to determine the soluble solids content ( ${ }^{\circ}$ Brix), which directly provides the percentage of soluble solids in the sugarcane juice. The stems of the middle part of the plant were evaluated by taking a juice sample from each plant, at a number of ten, for each bundle.

Using the $\mathrm{R}$ software ( $\mathrm{R}$ Development Core Team 2015), the data were submitted to the Shapiro \& Wilk's normality test at a 0.05 significance level ( $\mathrm{p} \geq 0.05)$ and, in the case of outliers, data with values 2.5 times greater than the interquartile range were removed, respecting the limit of $10 \%$ of the total observations for each treatment. Subsequently, the normal data were submitted to analysis of

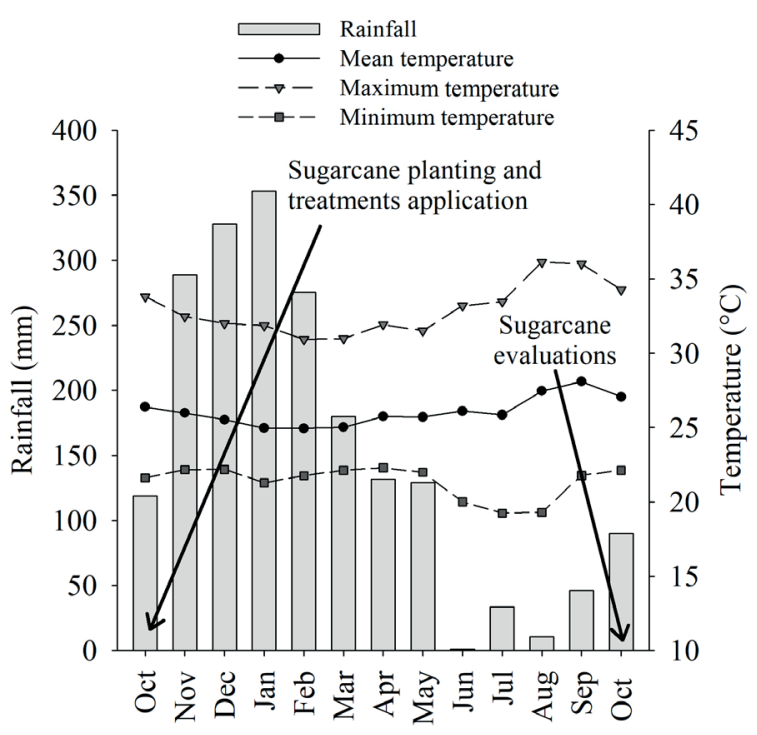

Figure 1 . Monthly precipitation and maximum, minimum and mean temperature during the sugarcane cycle, in a Dystrophic Red-Yellow Latosol. Data from the INPE weather station in Alta Floresta, Mato Grosso state, Brazil. 
variance by the $\mathrm{F}$ test $(\mathrm{p} \leq 0.05)$ and, when significant, a polynomial regression analysis was performed for $\mathrm{P}_{2} \mathrm{O}_{5}$ doses, adopting as selection criteria the models with the highest coefficient $\left(\mathrm{R}^{2}\right)$, the smallest residual sum of squares and the significance of the parameters of the equation $(p \leq 0.05)$. The means of the variables related to the factor sources of $\mathrm{P}$ were analyzed by the Tukey test at a 0.05 significance level $(\mathrm{p} \leq 0.05)$.

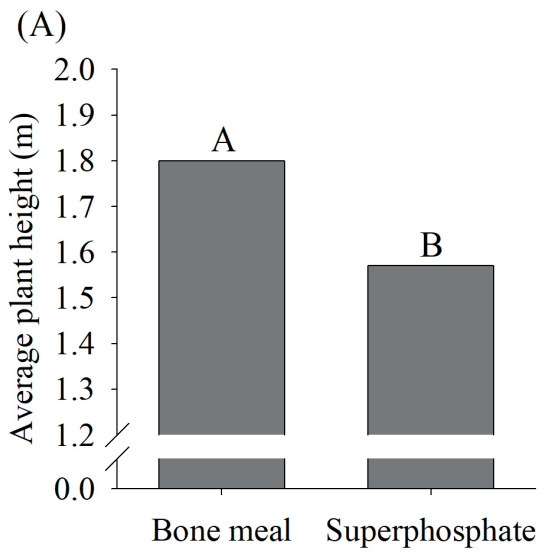

(B)

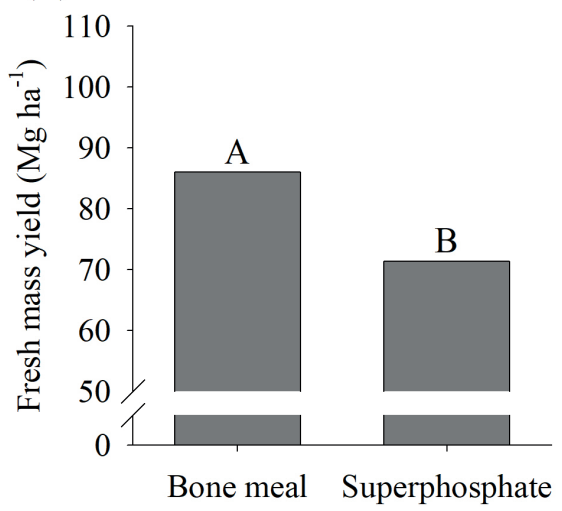

(C)

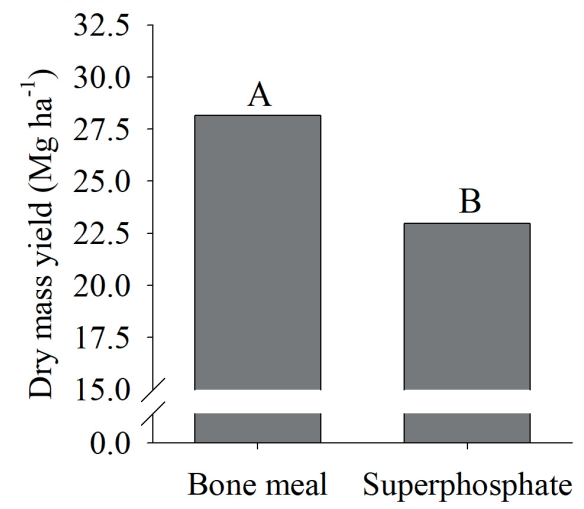

\section{RESULTS AND DISCUSSION}

The proposed sources and doses of P influenced the biometric and yield attributes of sugarcane; however, there were no significant interactions between doses and sources. Higher yields were observed for height, fresh mass, dry mass, plant mass and number of internodes of plants that were fertilized with bone meal (Figure 2). This increase was $13 \%$ for height, $18.4 \%$ for dry mass, $17 \%$ for fresh mass, $16.6 \%$ for plant mass and $15 \%$ for nodes, when compared to plants fertilized with single superphosphate. As described by Jeng et al. (2007) and Warren et al. (2009), bone meal is a source that is rich in $\mathrm{P}$, as much as phosphates of mineral origin are, and it has a high concentration of $\mathrm{Ca}$ (83.7-111.0 $\left.\mathrm{g} \mathrm{kg}^{-1}\right)$, an interesting alternative for nutritional supplementation of plants such as sugarcane in soils with first-year crops. A study by Caione et al. (2011) demonstrated the efficiency of phosphate fertilizers with bone meal in sugarcane
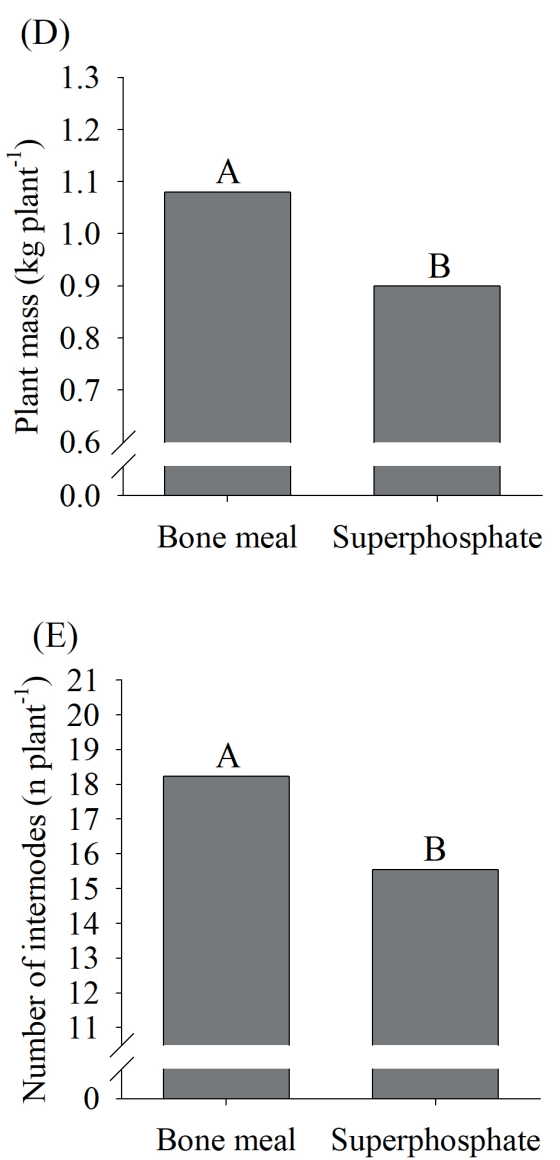

Figure 2. Mean values of biometric and yield attributes of sugarcane fertilized with sources of P. Means classified by the Tukey test at 0.05 of significance. 
crops, which showed a response similar to that of triple superphosphate fertilization in attributes such as plant height, number of tillers, fresh mass and dry mass. The authors reported that this effect possibly occurred due to some factors such as the climatic condition of the region, planned soil fertility and crop management practices (minimum planting and proximity between rows), whose main objective is to control undesirable plants and incorporate nutrients via topdressing fertilization, thereby improving the effect of phosphates.

The sugarcane attributes in response to $\mathrm{P}_{2} \mathrm{O}_{5}$ doses were described by quadratic functions (Figure 3). Thus, it was possible to calculate the
(A)

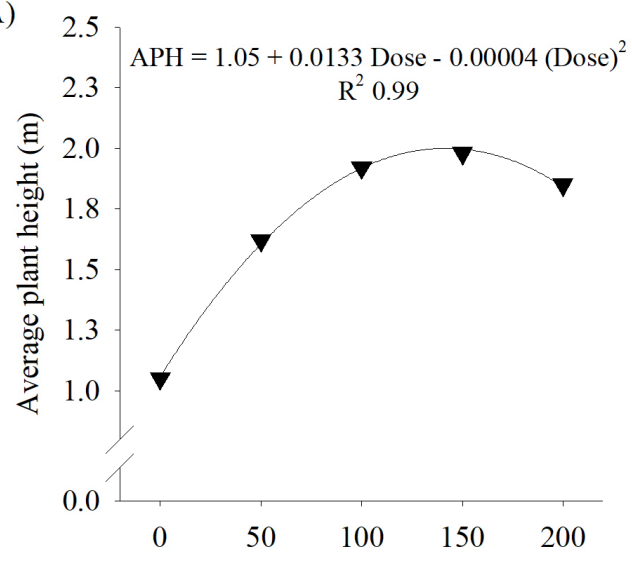

(C)

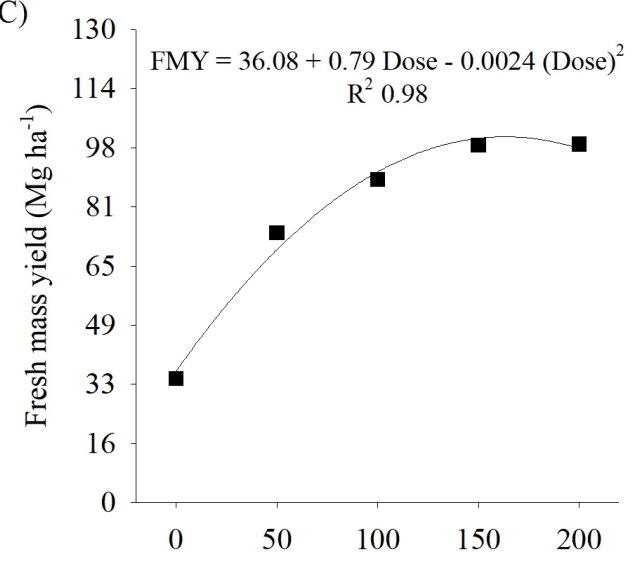

(E)

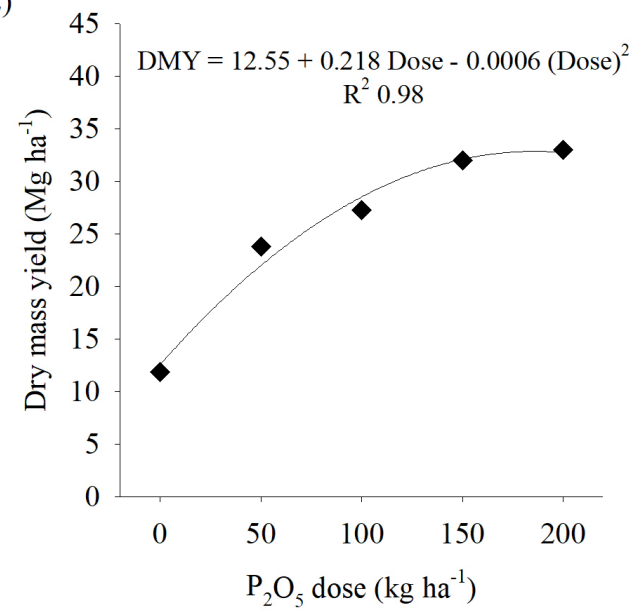

(B)

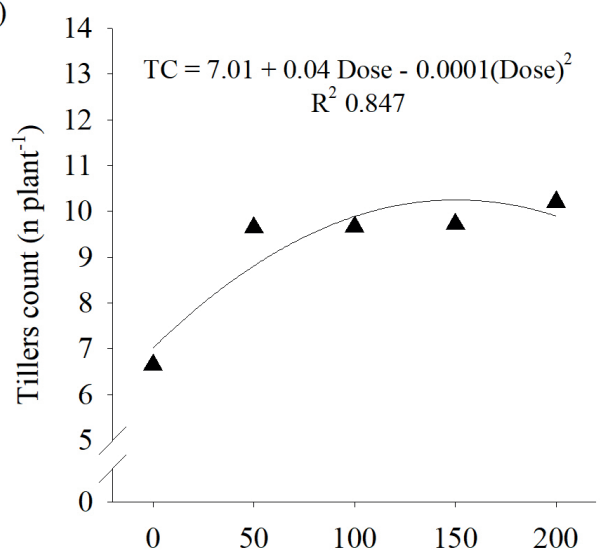

(D)

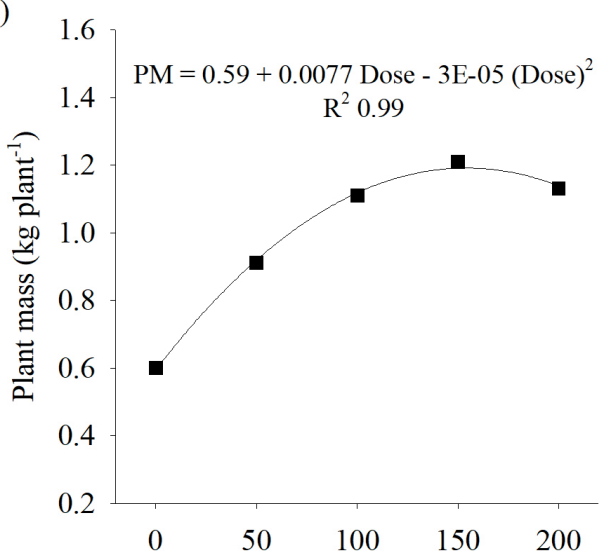

(F)

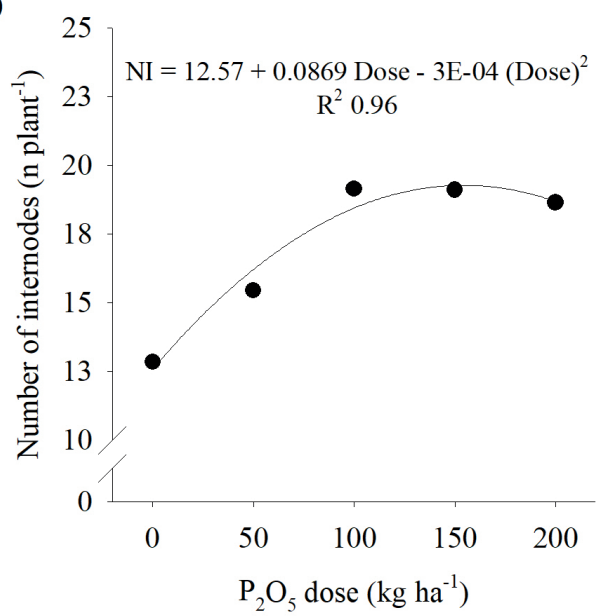

Figure 3. Sugarcane attributes: A) average plant height; B) tillers count; C) fresh mass yield; D) plant mass; E) dry mass yield; and F) number of internodes, according to the $\mathrm{P}_{2} \mathrm{O}_{5}$ doses applied in the furrows. 
$\mathrm{P}_{2} \mathrm{O}_{5}$ dose that provided the highest yield in the evaluated attributes. The dose of $150.40 \mathrm{~kg} \mathrm{ha}^{-1}$ of $\mathrm{P}_{2} \mathrm{O}_{5}$ provided the highest number of tillers $\left(10.24 \mathrm{n} \mathrm{plant}^{-1}\right) ; 154.09 \mathrm{~kg} \mathrm{ha}^{-1}$ the highest plant mass (1.19 kg plant $\left.{ }^{-1}\right) ; 154.24 \mathrm{~kg} \mathrm{ha}^{-1}$ the highest number of internodes (19 $\left.\mathrm{n} \mathrm{plant}^{-1}\right) ; 141.82 \mathrm{~kg} \mathrm{ha}^{-1}$ the highest plant height $(2.00 \mathrm{~m}) ; 163.24 \mathrm{~kg} \mathrm{ha}^{-1}$ the highest fresh mass (100.47 $\left.\mathrm{Mg} \mathrm{ha}^{-1}\right)$; and $186.06 \mathrm{~kg} \mathrm{ha}^{-1}$ the highest dry mass $\left(32.84 \mathrm{Mg} \mathrm{ha}^{-1}\right)$. The doses had no influence on the diameter of sugarcane stalks.

Based on the initial chemical characteristics of the soil under study, the available $\mathrm{P}$ content was classified as very low $\left(\leq 10 \mathrm{mg} \mathrm{dm}^{-3}\right)$, to which the fertilization with $150 \mathrm{~kg} \mathrm{ha}^{-1}$ of $\mathrm{P}_{2} \mathrm{O}_{5}$ is indicated for sugarcane crops, with an average expected yield above $120 \mathrm{Mg} \mathrm{ha}^{-1}$ of fresh mass (Ribeiro et al. 1999). The results confirm the accuracy of this recommendation, given that the doses that provided a maximum expression of the evaluated attributes were between $141.82 \mathrm{~kg} \mathrm{ha}^{-1}$ and $186.06 \mathrm{~kg} \mathrm{ha}^{-1}$ (Figure 3).

Based on the obtained results, it was clear that the initial condition of soil fertility exerts a direct influence on the efficiency of organic and mineral phosphate fertilization. In a planned fertility profile with $\mathrm{pH}$, base saturation and available $\mathrm{P}$ levels within the appropriate ranges, growers may have a lower fertilizer expenditure and greater responses of the sugarcane crop, expressing its maximum yield potential. Malavolta et al. (1955) reported that the organic phosphorus present in bone meal shows a faster release, when compared to natural phosphate fertilizers, providing sufficient amounts of the nutrient to meet the demands of corn and rice during their respective cycles. According to Malavolta et al. (2002), for the sweet potato crop, results of bone meal action were observed in the first 15 days after the application. Garcia et al. (2018) reported that the use of organic or organomineral sources protects $\mathrm{P}$ from being absorbed by the soil and, in addition, it may contribute to a decrease in production costs and also to a sustainable agriculture, with a more efficient use of fertilizers.

The efficiency of phosphate fertilization with bone meal was more evident with the responses of variables inherent to the nutritional status and quality of sugarcane, i.e., the concentration of $\mathrm{P}$ in the plant tissue and the amount of total soluble solids ( $\left.{ }^{\circ} \mathrm{Brix}\right)$. The ${ }^{\circ}$ Brix was negatively influenced by increasing $\mathrm{P}_{2} \mathrm{O}_{5}$ doses in both the $\mathrm{P}$ sources tested (Figure 4A). Such behavior was described by linear functions

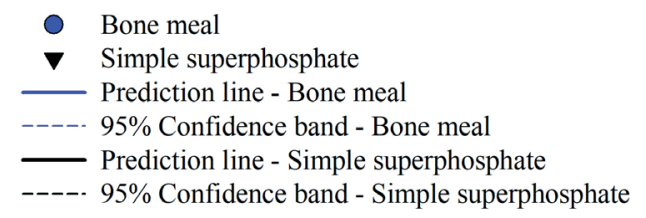

(A)

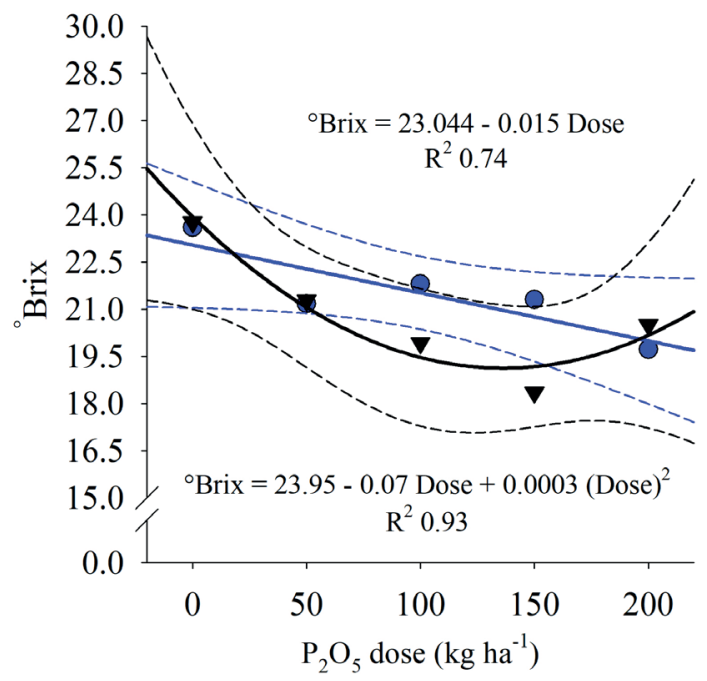

(B)

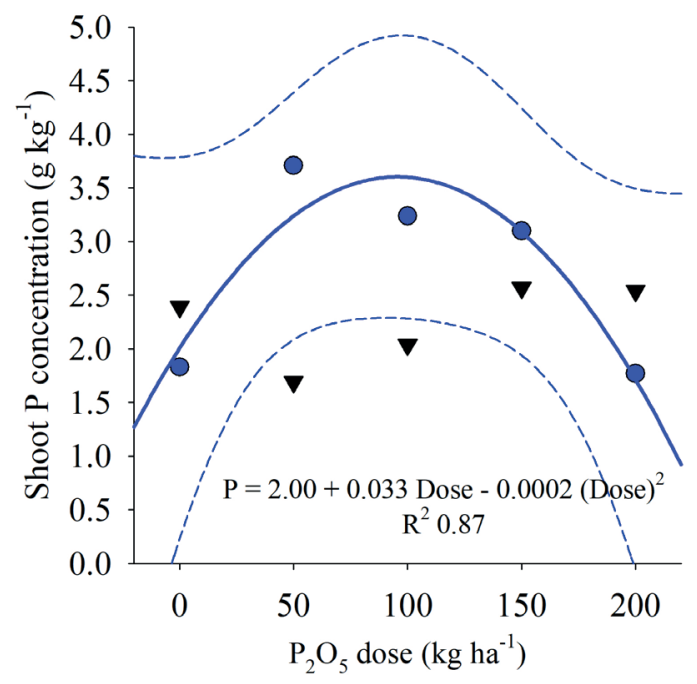

Figure 4. Progress of the interaction between sources of $\mathrm{P}$ and doses of $\mathrm{P}_{2} \mathrm{O}_{5}$ for soluble solids content $\left({ }^{\circ} \mathrm{Brix}\right)(\mathrm{A})$ and concentration of $\mathrm{P}$ in the plant tissue (B). 
using bone meal as a source of $\mathrm{P}$, and quadratic functions using single superphosphate. These results are clearly justified by the effect of soluble sugars dilution in tissues of the plant. In addition to increasing the fresh mass, the other variables (number of tillers and plant height) were positively influenced by the $\mathrm{P}_{2} \mathrm{O}_{5}$ doses, what supports the results obtained for the soluble solids content ( ${ }^{\circ} \mathrm{Brix}$ ) (Figures 3 and 4C). The higher plant development observed with the increase of the P doses up to the maximum response is due to the synergy existing with nitrogen ions, promoting its absorption by plants (Mahadevaiah et al. 2007).

As can be seen by comparing the proposed sources of $\mathrm{P}$ at doses of $100 \mathrm{~kg} \mathrm{ha}^{-1}$ and $150 \mathrm{~kg} \mathrm{ha}^{-1}$ of $\mathrm{P}_{2} \mathrm{O}_{5}$, the ${ }^{\circ}$ Brix was higher in $8.62 \%$ and $13.84 \%$, respectively, in plants fertilized with bone meal (Figure 4A). For the concentration of $\mathrm{P}$ in the plant tissues, the doses of $50 \mathrm{~kg} \mathrm{ha}^{-1}$ and $100 \mathrm{~kg} \mathrm{ha}^{-1}$ indicated that the fertilization with bone meal was $54.44 \%$ and $37.04 \%$, respectively, being more efficient for the mineral nutrition of sugarcane than that with single superphosphate (Figure 4B).

No significant difference was observed for the concentration of $\mathrm{P}$ in sugarcane tissues, in line with the $\mathrm{P}_{2} \mathrm{O}_{5}$ doses using the single superphosphate source (Figure 4B). On the other hand, a quadratic behavior was observed for that same variable using bone meal. The dose of $95.80 \mathrm{~kg} \mathrm{ha}^{-1}$ of $\mathrm{P}_{2} \mathrm{O}_{5}$ provided the highest concentration of $\mathrm{P}$ in the plant tissue $\left(3.60 \mathrm{~g} \mathrm{~kg}^{-1}\right)$.

The results obtained in the present study confirm the observations by Withers et al. (2018) on the dynamics of using P in Brazilian soils. These authors reported a prospect of shortage of phosphate fertilizers of mineral origin and the need to think of production systems that rationalize the use of $P$. An alternative approach is the use of "secondary phosphorus", found in animal production waste or in sugarcane processing residues, for example, which is already used in Australia. Estimates indicate that secondary phosphorus shall supply up to $20 \%$ of the Brazilian grain demand by 2050 , with investment in nutrient recovery technologies.

In this regard, more studies using alternative sources of $\mathrm{P}$, which fall under the so-called secondary phosphorus, should be carried out, mainly in large crops such as soybean, corn and bean, in order to verify the efficiency of the use of $P$ in crops and their dynamics in the agricultural system in different soil types and climatic regions.

\section{CONCLUSIONS}

1. The dose of $95.80 \mathrm{~kg} \mathrm{ha}^{-1}$ of $\mathrm{P}_{2} \mathrm{O}_{5}$ added to the source of bone meal provided the highest concentration of phosphorus in the sugarcane tissue $\left(3.60 \mathrm{~g} \mathrm{~kg}^{-1}\right)$;

2. The total soluble solids content of sugarcane was negatively influenced by the increase of the $\mathrm{P}_{2} \mathrm{O}_{5}$ doses in both the sources of $\mathrm{P}$ tested. However, with bone meal, the total soluble solids content was higher, when compared to that of plants fertilized with single superphosphate, at doses of $100 \mathrm{~kg} \mathrm{ha}^{-1}$ and $150 \mathrm{~kg} \mathrm{ha}^{-1}$ of $\mathrm{P}_{2} \mathrm{O}_{5}$;

3. Bone meal proved to be superior to single superphosphate, in terms of plant breeding attributes such as plant height, number of nodes, fresh mass, dry mass and plant mass.

\section{REFERENCES}

BLACKBURN, F. Sugar-cane. London: Longman, 1984.

BOEN, A.; HARALDSEN, T. K. Meat and bone meal and biosolids as slow-release phosphorus fertilizers. Agricultural and Food Science, v. 22, n. 2, p. 235-246, 2013.

CAIONE, G. et al. Fontes de fósforo para adubação de cana-de-açúcar forrageira no Cerrado. Pesquisa Agropecuária Tropical, v. 41, n. 1, p. 189-196, 2011.

CAIONE, G.; FERNANDES, F. M.; LANGE, A. Residual effect of phosphorus sources in soil chemical properties, nutrition and biomass productivity of sugarcane. Revista Brasileira de Ciências Agrárias, v. 8, n. 2, p. 189-196, 2013.

CASAGRANDE, J. C. et al. Adsorção de fosfato e sulfato em solos com cargas elétricas variáveis. Revista Brasileira de Ciência do Solo, v. 27, n. 1, p. 51-59, 2003.

CAVALLARO JÚNIOR, M. L. Fertilizantes orgânicos e minerais como fontes de $\mathrm{N}$ e de $\mathrm{P}$ para produção de rúcula e tomate. 2006. 39 f. Dissertação (Mestrado em Tecnologia da Produção Agrícola) - Instituto Agronômico, Campinas, 2006.

EMPRESA BRASILEIRA DE PESQUISA AGROPECUARIA (Embrapa). Sistema brasileiro de classificação de solos. Brasília, DF: Embrapa Solos, 2018.

GARCIA, J. C. et al. Fontes de fósforo mineral e organomineral no estado nutricional e no crescimento inicial da cana-de-açúcar. Nucleus, v. 15, n. 1, p. 523531, 2018.

GRANT, C. A. et al. A importância do fósforo no desenvolvimento inicial da planta. Piracicaba: Potafos, 2001. (Informações agronômicas, 95). 
HAYNES, R. J. Effects of liming on phosphate availability in acid soils: a critical review. Plant Soil, v. 68, n. 3, p. 289-308, 1982.

JENG, A. S. et al. Meat and bone meal as nitrogen and phosphorus fertilizer to cereals and rye grass. In: BATIONO, A. et al. Advances in integrated soil fertility management in sub-Saharan Africa: challenges and opportunities. Dordrecht: Springer, 2007. p. 245-253.

LANDELL, M. G. A. et al. A variedade IAC86-2480 como nova opção de cana-de-açúcar para fins forrageiros: manejo de produção e uso na alimentação animal. Campinas: IAC, 2002. (Boletim técnico, 193).

LOCHER, K. P. Mechanistic diversity in ATP-binding cassette (ABC) transporters. Nature Structural and Molecular Biology, v. 23, n. 6, p. 467-493, 2016.

MAHADEVAIAH, M. S. et al. Simple spectrophotometric determination of phosphate in sugarcane juices, water and detergent samples. E-Journal of Chemistry, v. 4, n. 4, p. 467-473, 2007.

MALAVOLTA, E. et al. Aproveitamento de alguns adubos fosfatados pelo milho (Zea mays) e pelo arroz (Oryza sativa) em terra roxa misturada. Revista de Agricultura, v. 30, n. 1, p. 185-197, 1955.

MALAVOLTA, E.; GOMES, F. P.; ALCARDE, J. C. Adubos e adubações. São Paulo: Nobel, 2002.

MALAVOLTA, E.; VITTI, G. C.; OLIVEIRA, S. A. Avaliação do estado nutricional das plantas: princípios e aplicações. 2. ed. Piracicaba: Associação Brasileira para Pesquisa da Potassa e do Fosfato, 1997.

OLIVEIRA JÚNIOR, A. D. et al. Marcha de absorção e acúmulo de macronutrientes em soja com tipo de crescimento indeterminado. In: REUNIÃO DE
PESQUISA DE SOJA, 34., 2014, Londrina. Resumos expandidos... Londrina: Embrapa Soja, 2014. p. 133-136.

OLIVEIRA, M. W. et al. Nutrição mineral e adubação da cana-de-açúcar. Informe Agropecuário, v. 239, n. 28, p. 30-43, 2007.

R DEVELOPMENT CORE TEAM. $R$ : a language and environment for statistical computing. Vienna: R Foundation for Statistical Computing, 2015.

RIBEIRO, A. C. et al. Recomendações para o uso de corretivos e fertilizantes em Minas Gerais: $5^{\text {a }}$ aproximação. Viçosa: Comissão de Fertilidade do Solo do Estado de Minas Gerais, 1999.

SUNDARA, B.; NATARAJAN, V.; HARI, K. Influence of phosphorus solubilizing bacteria on the changes in soil available phosphorus and sugarcane and sugar yields. Field Crops Research, v. 77, n. 1, p. 43-49, 2002.

VON PINHO, R. G. et al. Marcha de absorção de macronutrientes e acúmulo de matéria seca em milho. Revista Brasileira de Milho e Sorgo, v. 8, n. 2, p. 157173, 2010.

WARREN, G. P.; ROBINSON, J. S.; SOMEUS, E. Dissolution of phosphorus from animal bone char in 12 soils. Nutrient Cycling in Agroecosystems, v. 84, n. 2, p. 167-178, 2009.

WITHERS, P. J. et al. Transitions to sustainable management of phosphorus in Brazilian agriculture. Scientific Reports, v. 8, e2537, 2018.

YEAGLE, P. L. The membrane of cells. 3. ed. New York: Academic Press, 2016.

ZOBIOLE, L. H. et al. Marcha de absorção de macronutrientes na cultura do girassol. Revista Brasileira de Ciência do Solo, v. 34, n. 2, p. 425-433, 2010. 